\title{
Measuring the restrictiveness of (macro)prudential policy: the case of bank capital regulation in Poland
}

\author{
Marcin Czaplicki ${ }^{1}$ (1)
}

Accepted: 4 June 2021 / Published online: 23 June 2021

(c) The Author(s), under exclusive licence to Springer Nature Limited 2021

\begin{abstract}
The heterogeneity of the banking sector is a vital problem both in case of the conduct of macroprudential policy, as well as the assessment of its effectiveness. To address this issue, we construct a new measure of macroprudential policy restrictiveness, the bank's free lending capacity ratio (the quotient of a new lending a bank can extend given its capital surplus above capital requirement, and its current volume of loans). We describe its advantages over the measures used in the previous research. Finally, employing first difference GMM method on (dynamic) panel data series, we explain the drivers of changes in lending growth of stock-listed banks in Poland between 2010 and 2020. We show that the free lending capacity ratio displays the most convincing results among the examined variables, pointing at its usefulness both in explaining and evaluating the impact of prudential regulation on banking activity, as well as in understanding potential issues in the transmission of monetary policy via the banking sector, resulting from its heterogeneity. Finally, we draw practical and policy-related conclusions, as regards the measurement of macroprudential policy restrictiveness.
\end{abstract}

Keywords Macroprudential policy · Macroprudential regulation · Loan supply · Capital adequacy · Lending capacity · Poland

JEL Classification E51 $\cdot \mathrm{G} 18 \cdot \mathrm{G} 21 \cdot \mathrm{G} 28$

\section{Introduction}

After the global financial crisis, changes have been introduced to bank capital regulation that were intended to strengthen the resilience of the banking sector as a whole. As such the new regulation has been called macroprudential, as opposed to the pre-crisis microprudential approach. The most visible step forward has been the creation of various capital buffers that serve as add-ons to the standard 8\% ratio of own funds to risk-weighted assets. Higher capital is intended to make banks more safe, but also to protect the entire banking sector, and the real economy from periods of excessive credit creation, which (known as unstable credit booms) have been so far the most repetitive source of financial crises (see Schularick and Taylor [51] of Laeven and Valencia [41]).

Marcin Czaplicki

marcin.czaplicki@sgh.waw.pl

1 Institute of Risk and Financial Markets, Warsaw School of Economics, Warsaw, Poland
The differentiation of required capital ratios among banks creates a new space for research, related not only to the interaction of (macro)prudential policy with other macroeconomic policies (first and foremost with the monetary policy, for example, Borio and Zhu [14], Cecchetti and Kohler [20], Agur and Demertzis [1]), but also to the measurement, and assessment of macroprudential policy effectiveness. Both of these strands of research meet in the rapidly developing literature on the impact of bank capital on the efficacy of monetary policy in the environment of low (or negative) interest rates. A notable example is the reversal interest rate, a notion coined by Brunnermeier and Koby [16] who determine its value (among others) by bank's initial capital position in relation to capital requirements.

That said, the relation between the possessed and required capital is of a vital importance not only for the prudential, but also for monetary policy. Under regulatory capital requirements, banks are obliged to put aside certain amount of own funds for each unit of credit they grant. The more capital is needed for each unit of credit the harder it is (as equity is the most expensive source of funding) to expand 
the balance sheet. Given a limitation from capital requirements, a bank wishing to expand its business can either increase the numerator, that is expand own funds, or lower the denominator by reducing the risk-weighted assets. There are different ways to achieve the above mentioned targets. A bank can issue new equity or subordinated debt. It may also retain a bigger chunk of its earnings. On the active side, it may shift assets into less risk-heavy ones (for example, from corporate to mortgage loans or government debt) or apply internal risk measurement methods which usually lead to lower (internal) credit risk weights.

These possibilities are not reflected, however, in the previous assessment/evaluation of regulatory capital stringency, focusing on simple indicators such as capital adequacy ratio, or its surplus over the combined capital requirement. As a result, single banks, as well as entire sectors, may be erroneously regarded as being more/less overburdened with capital requirements, which is further explained in the following parts of the article. That said, the macroprudential policy may falsely be regarded as less/more stringent providing biased hints for the policymakers. Therefore, the goal of this article is to provide a new, more robust measure of macroprudential policy tightness.

Our measure, the free lending capacity ratio (FLCR) allows to address the issue of heterogeneity in cross-country/ cross-entity panel studies by including both the structure of regulatory capital, bank assets (incl. loans), as well as the approach to measure bank risk, which all differ among banks, resulting in visible differences between (but also inside) local banking sectors. We estimate the impact of changing capital requirements on bank lending in Poland showing that the FLCR proves more robust in explaining changes to bank lending activity than other capital-related measures. That said, we provide regulators and central bankers with a promising tool to measure the effects of their policy and to adjust it to achieve financial or macroeconomic stability targets.

Poland provides a particularly interesting playground for a research on the above mentioned interactions, as the financial supervisor (Komisja Nadzoru Finansowego, KNF) actively adjusted capital regulation (in both directions) as one of its main policy tools before and after the implementation of Basel III in the form of CRD IV/CRR package (2015/2016). As a result of higher capital requirements, the banking sector slowed down the lending expansion, with some banks that found their free lending capacity negative, temporarily reducing the loan portfolio.

The remainder of the paper is organised as follows. The next section reviews the literature on the measurement of macroprudential policy effectiveness. The following one focuses on the capital adequacy, introducing and explaining free lending capacity ratio as a new measure of regulatory capital stringency. In Sect. 4, we discuss the data and describe the econometric models we employed in our study. Section 5 presents the empirical results, as well as the robustness checks. The last section concludes.

\section{Measuring the impact of macroprudential policy: literature review}

The evaluation of the efficacy of macroprudential policy is a popular topic among researchers, who (using mostly panel regressions) study the impact of various prudential instruments on credit and debt-related variables, as well as credit and asset (incl. housing) prices. It has been mostly conducted on a discretional (or even binary) basis, as the plethora of instruments that have been already introduced, had not enough in common to organise them in any consistent order (to state if one action or tool is more or less restrictive than the other). Early studies either used a single or cumulative dummy variables to assess the impact of an introduction or change to a specific prudential policy tool. Lim et al. [45], Tovar et al. [53], or Arregui et al. [7] utilised them in their respective event studies. Kuttner and Shim [40] expanded this type of analysis by adding up the $(-1,0,+1)$ dummy variables, if during one period there was more than one policy action taken. Crowe et al. [24] used a case-study approach to assess the impact of several macroprudential tools on housing market. Claessens et al. [23], as well as Geršl and Jašová [33] utilised a binary approach to label the period when a distinct measure was effective.

Vandenbussche et al. [54] introduced a somewhat more sophisticated measures of macroprudential policy tightness. They code the changes in distinct (macro)prudential policy instruments to differentiate their severity (for example, an introduction of a $60 \%$ maximum LTV (loan-to-value) ratio is less restrictive than of a $100 \%$ one). They also tackled the issue of changes in capital requirements for banks (pp. change of total capital requirement).

The discreteness of the macroprudential policy data was one of the most crucial issues that made it harder to study the impact of prudential measures on financial sector. The most popular way to address it is the construction of composite measures covering the impact of several more or less related variables (see for example Ostry et al. [47], Zhang and Zoli [56], Bruno et al. [15]). The construction of these "macroprudential policy indexes" quickly gained on popularity (see Fendoğlu [29], Cerutti et al. [21], Akinci and OlmsteadRumsey [3] who additionally calculated separate indexes for policy tightening and loosening). Meuleman and Vander Vennet [46] expanded the macroprudential policy index prepared by Budnik and Kleibl [17] by weighting the specific changes in an instrument to construct the life cycle of a policy action over time. They did not differentiate between distinct tools, however, aggregating the overall index using 
equal weights. Alam et al. [4] have integrated the databases constructed in the previously mentioned papers in a comprehensive database containing monthly binary information on 17 policy measures for 134 countries from 1990 to 2016. Cizel et al. [22] distinguished between price- and quantitybased measures to address the issue of boundary problem, as dummy variables contained in most of the databases do not allow to assess the size/scale of the impact of distinct instruments. Araujo et al. [6] provide a meta-analysis basing on estimations from 58 previous empirical research pieces.

Kuttner and Shim [40] emphasised that the simplification in form of using categorical (binary) rather than numerical variables, whilst evaluating the effectiveness of macroprudential policy results from data heterogeneity (see also Carreras et al. [18]). Indeed, even the use of similar prudential instruments like DTI (debt-to-income) or LTV (loan-tovalue) ratios cannot be easily evaluated as the distinct measures targeted (among others) different types of property, various borrowers, or lenders (see Lee [43], who analysed the case of South Korea, where LTV and DTI ratio have been differentiated according to the property type, geographical location, loan maturity, financial institution (lender) or even borrower's marital status). A number of studies attempted to address this problem. Tillmann [52] and Lee et al. [44] employed a Qual VAR (VAR augmented by qualitative variables) to convert binary data on macroprudential shocks into more continuous ones. Zhang and Tressel [55] mapped various macroprudential policy instruments to factors that affect changes in bank lending standards (for example, they did not use dummies for LTV requirements, but looked at changes in LTV lending standards from bank surveys). Dumičic [27], apart from using a "traditional" macroprudential policy index, employed actual values (in per cent or percentage point) of general reserve requirements, LTV, as well as DTI ratios. Finally, some studies utilised changes in regulatory instruments, like dynamic provisioning mechanism (Jiménez et al. [38]) or LTV ratio (Richter et al. [49]). Galati and Moessner [31] and Poghosyan [48] offer a compact summary of the studies on the efficacy of macroprudential policy.

\section{The effectiveness of bank capital regulation}

The increasing unification (via Basel Accords) and utilisation (due to the introduction of Basel III) of capital buffers offer a promising field for research evaluating the impact and efficacy of supply-side-oriented prudential instruments. In the world of Basel Committee-shaped capital requirements, every bank has to look at its capital (own funds) as it takes decision on the expansion of the balance sheet. As each bank has to put aside certain amount of own funds for each unit of credit, it becomes a conventional wisdom that weak banks tend to originate less credit. Indeed, Altavilla et al. [5] show that lower credit growth among weaker banks may result both from a weak supply, as well as low demand for funds, which depends on financial intermediaries own characteristics, such as risk profile and funding. Gambacorta and Shin [32] pointed out that bank equity is an important determinant of both the bank's funding cost and its lending growth. Banks with higher capital show higher lending growth due to the lower funding costs. A study of European Banking Authority [28] found substantial beneficial supply effects of greater bank capital in a cross-country study of European banks.

\section{Measurement of capital requirements in economic literature}

Capital regulation and requirements, as well as their impact on bank lending have been in the spotlight of empirical researchers since many years. Bernanke and Lown [10] showed a significant link between banks' capital-asset ratios and lending growth, arguing that a capital crunch might have worsened the 1990 recession in the USA. Hancock and Wilcox [34] stipulated that bank credit action might have slowed in 1990, due to shortfalls of bank's equity capital, as some of them reduced lending in order to satisfy the capital requirement. That said, they were (to our knowledge) the first to point at the notion of surplus capital of banks. Heid et al. [35] found that the reaction of banks to changes in capital requirements depends on their capital buffer (difference between the actual and required capital ratio). That said, the notion of bank capital buffers was widely used in economic literature before and during the Global Financial Crisis (see Fonseca et al. [30] for a very thorough review of related literature), as (at constant requirements) they allowed for measuring the changes in (relative) regulatory restrictiveness.

The utilisation of capital buffers as a determinant of bank lending gained attention following the Global Financial Crisis, however, in particular after regulators started increasing the requirements. A number of studies dealt with this issue. Berrospide and Edge [11] found a positive impact of capital adequacy ratio, as well as surplus capital on bank lending. Aiyar et al. [2] measured the changes in minimum capital requirements on banks lending expansion. More recently, several studies, including i.a. Gambacorta and Shin [32], Borio and Gambacorta [13], Catalán et al. [19], Kapuściński [39], and Deutsche Bundesbank [26] utilised difference between banks' CAR and regulatory capital requirements as an explanatory factor in bank lending models. Gambacorta and Shin [32] defined the "free bank capital" as capital in excess of minimum capital requirements. Borio and Gambacorta [13] labelled the difference between the regulatory capital ratio and the regulatory minimum as "banks regulatory capital buffer". Catalán et al. [19] introduced the 
name "capital ratio distance" with the exact same definition. Kapuściński [39] called it, simply, the "capital buffer", whilst Deutsche Bundesbank [26] used the name "excess capital buffer". De Jonghe et al. [25] did not explicitly calculate the capital buffers, but they followed similar idea, as they model various measures of credit expansion using required and actual capital ratio at once. Finally, Imbierowicz et al. [37] are the first (to our knowledge), who dig deeper and broaden utilise the risk density (ratio of risk-weighted assets to total assets) to capture a bank's total regulatory capital requirement related to corporate lending. They stressed out that the key reason behind applying this approach was the fact that banks with a lower average risk weight of assets are less exposed to a change in capital requirements.

The studies found the capital buffer (henceforth, we will use the term free capital buffer, FCB) to be statistically significant in explaining changes in bank lending. Catalán et al. [19] additionally found that the response of weaker banks to changes in their capital position is larger than that of stronger banks. Therefore, not only the level of capital, but also its distribution across banks in the financial system affects the transmission of shocks to aggregate lending. Gambacorta and Shin [32] showed that banks hold significant discretionary Tier 1 capital in excess of the $25 \%$ regulatory maximum of risk-weighted assets.

The free capital buffer has its indisputable benefits as a measure of the stringency of macroprudential policy. It is a simple and therefore easily understandable measure allowing to tackle some of the flows related to the usage of (even simpler) total required capital ratio (henceforth TCR - total capital requirement), which does not enable to differentiate between the banks fulfilling (or not) the capital requirements. Free capital buffer has its own flows too, however, as it does not allow for a full (relative) assessment of regulatory stringency. A low buffer between the CAR and TCR, may not necessarily reflect a weak capital position of a bank (for example 9\% CAR vs. required TCR of $8 \%$ ), but a very conservative macroprudential policy of a supervisory authority (for example, $19 \%$ vs. required $18 \%$ ). In such a case a free capital ratio, defined as $\frac{\text { Free Capital Buffer }}{\text { CAR }}$ could indicate the portion of bank own funds that is free to use and could finance bank's (lending) expansion. Although the latter measure encompasses both the strengths of the earlier (free capital buffer), it addresses only some of its weaknesses. They are mostly related to the construction of capital adequacy requirements, which use the notion of own funds in the numerator and risk-weighted assets in the denominator. The issue of risk weighting has been indicated as one of the crucial factors behind the severity of the global financial crisis (see for example Blundell-Wignall and Atkinson [12], who showed that simple leverage ratio had been a better predictor of bank losses than CAR). A bank can decrease the capital requirement via shifts to "less risky" portfolio, use of advanced measurement approaches or external guarantees for a part of its portfolio. All in all, such arbitrage may lead to a situation, when two banks have a free capital buffer of, say, $2 \%$, but with assets (or loans) characterised by average risk weight of $35 \%$ and $70 \%$, respectively, will not find the regulatory capital requirements equally stringent. The first bank will be able to extend two times more loans (in relation to its own funds) than the other one, having a visibly higher impact on its profitability. Hence, if a panel exercise compares banks that use standard approach, having average risk weights of $60-80 \%$ with those using advanced approaches lowering these weights to as low as $20-40 \%$ they may provide misleading conclusions. Accounting for this can reduce the impact, the heterogeneity of the banking sector has on the results of empirical studies employing cross section (panel) methods.

\section{Measuring the restrictiveness of bank capital regulations: a new approach}

In this article, we introduce a new measure of bank's capital position (and (macro)prudential regulations restrictiveness) - the free lending capacity ratio-defined as the quotient of free lending capacity and outstanding volume of loans. The free lending capacity is calculated as a difference between the outstanding volume of loans and the maximum loan volume that could be extended with current bank capital assuming unchanged loan portfolio average risk weight, and the share of credit risk in total bank risk (see Eq. 1).

$\mathrm{FLC}=\frac{(\mathrm{CAR}-\mathrm{TCR})}{\mathrm{CAR}} \times \frac{\mathrm{CRR}}{\mathrm{TRR}} \times$ OwnFunds $\times \frac{1}{\mathrm{AvgRW}} \times \frac{1}{\mathrm{TCR}}$

where FLC—bank's free lending capacity; CAR—bank's capital adequacy ratio; TCR - total (regulatory) capital requirement $=8 \%+$ all buffers (countercyclical, conservation, systemic, SII, OSI) + III Pillar add-ons + others; OwnFunds - bank's total own funds $=$ Tier I + Tier II (and Tier III before the introduction of Basel III rules); CRR-regulatory capital requirement for credit risk (amount of own funds necessary to cover credit risk under $8 \%$ capital adequacy ratio); TRR - total regulatory capital requirement (amount of own funds necessary to cover total bank risk under $8 \%$ capital adequacy ratio); AvgRW — average risk weight of the credit portfolio.

The FLC ratio (FLCR) is calculated as follows: 
FLCR $=\frac{(\mathrm{CAR}-\mathrm{TCR})}{\mathrm{CAR}} \times \frac{\mathrm{CRR}}{\mathrm{TRR}} \times$ OwnFunds $\times \frac{1}{\mathrm{AvgRW}} \times \frac{1}{\mathrm{TCR}} \times \frac{1}{\text { Total Loans }}$

where TotalLoans-bank's outstanding loan volume.

Firstly, we take the ratio of bank's free capital buffer to bank's capital adequacy requirement. Doing so, we know the fraction of the capital adequacy ratio that is still available to extend bank's activities (first of all to expand lending volume). Secondly, we determine the share of credit risk in total risk of a bank. As a result, we recognise, how much out of the above mentioned fraction of CAR would likely be directed at new lending. As a third step, we calculate the actual volume of this new lending, knowing the a) size of bank's own funds, b) the risk weight of the outstanding loan portfolio (to simplify, we assume that it does not change over time), as well as c) the number of units of own funds a bank needs to secure for a unit of an average loan. Finally, we divide this amount, that is the free lending capacity by the outstanding lending volume. As a result, we know the extent to which the bank can increase its current loan portfolio given the free capital buffer, TCR (regulatory requirements), average risk weight (risk characteristics) and own funds (capitalisation). Importantly, this is also the limit of the impact of monetary policy accommodation on banking activity (ceteris paribus). As such it could be easily included in theoretical or empirical models evaluating the efficacy of monetary policy. Moreover, it also shows, why the effects of changes to monetary policy may not be linear, as at some point its impact may be hampered by a reduced space for lending expansion.

As complicated, as our measure seems to be, it entails the basic characteristics of the regulatory impact on the supply side of bank lending, that is: (1) how much own funds does a bank have for granting new credit $\left(\frac{(\mathrm{CAR}-\mathrm{TCR})}{\mathrm{CAR}} \times \frac{\mathrm{CRR}}{\mathrm{TRR}} \times\right.$ OwnFunds $),{ }^{1}(2)$ how much credit can it grant out of these own funds $\left(\frac{1}{\operatorname{AvgRW}} \times \frac{1}{\mathrm{TCR}}\right)^{2}$ and (3) what is the relation between the available extension of our lending portfolio and the current lending volume $\left(\frac{1}{\text { TotalLoans }}\right)$. Below we carry out some arithmetical operations to simplify Eq. 2, thus making it easier to use, given the scarcity of bank related data.

Knowing that:

\footnotetext{
1 The more own funds to grant new loans a bank has, the bigger its surplus capital, the more it is devoted to lending activity, rather to other forms of business, as well as the higher the own funds themselves).

${ }^{2}$ Out of a 1 unit of own funds, a bank can extend the more credit, the lower the risk (weight) of the borrower, and the lower the regulatory capital requirement.
}

$\mathrm{CAR}=\frac{\text { OwnFunds }}{\mathrm{TRR}} \times \mathrm{TCR}$

and $\quad \mathrm{CRR}=$ TotalLoans $\times \mathrm{TCR} \times$ AvgRW.

We get:

$\mathrm{FLCR}=(\mathrm{CAR}-\mathrm{TCR}) \times \frac{1}{\mathrm{TCR}}$.

Thus, the final equation for the free lending capacity is as follows:

FLCR $=\frac{(\text { CAR }- \text { TCR })}{\text { TCR }}=\frac{\text { Free Capital Buffer }}{\text { TCR }}$.

The measure we introduce has similar pros, as a simpler free capital buffer, as it varies over time, even when capital requirements remain flat (macroprudential policy does not change, which, as in the case of a distinction between real and nominal interest rates could also imply a (sometimes unwilling) policy tightening or loosening). The FLCR adds the relativity in assessing the stringency of this buffer, as it compares its size to the capital requirement. That said, it may enable to distinguish between jurisdictions with more or less restrictive regulations improving the credibility of cross-country studies that evaluate the efficacy of macroprudential (and monetary) policy. Furthermore, as it allows to distinguish the impact of regulation on individual banks within the same jurisdiction (for example, a small one with a CAR of, say, $12.5 \%$ and free capital buffer of $2 \%$, and a bigger, systemically important one with a CAR of, say, $22.0 \%$ and a free capital buffer of $2 \%$ ) further increasing the reliability of the results of panel studies that use bank-level data. Our measure does not address the problem of different sources of own funds, however, as banks could issue more Tier II capital to improve their regulatory capital stance. One way to tackle this issue might be to use Tier I or Common Equity Tier I based FLCR, whichever would be more binding for the lender.

\section{Data description}

In the study that follows, we scrutinise the interrelations between the free lending capacity ratio and bank lending. We use bank-specific (micro) data (quarterly data for 2q2009-3q2020 ${ }^{3}$ ) for all 11 banks listed on the Warsaw

\footnotetext{
3 The actual dataset starts in 1q2010, as we wanted to avoid the $y / y$ lending dynamics being based on a crisis hit 2009 figures. However, some explanatory variables related to bank capital position are
} 
Fig. 1 The ratio of sample banks loans and assets to total sector loans and assets (2009-2020). Source: NBP, $\mathrm{KNF}, \mathrm{KNB}$, Banks' financial statements. Author's own calculations

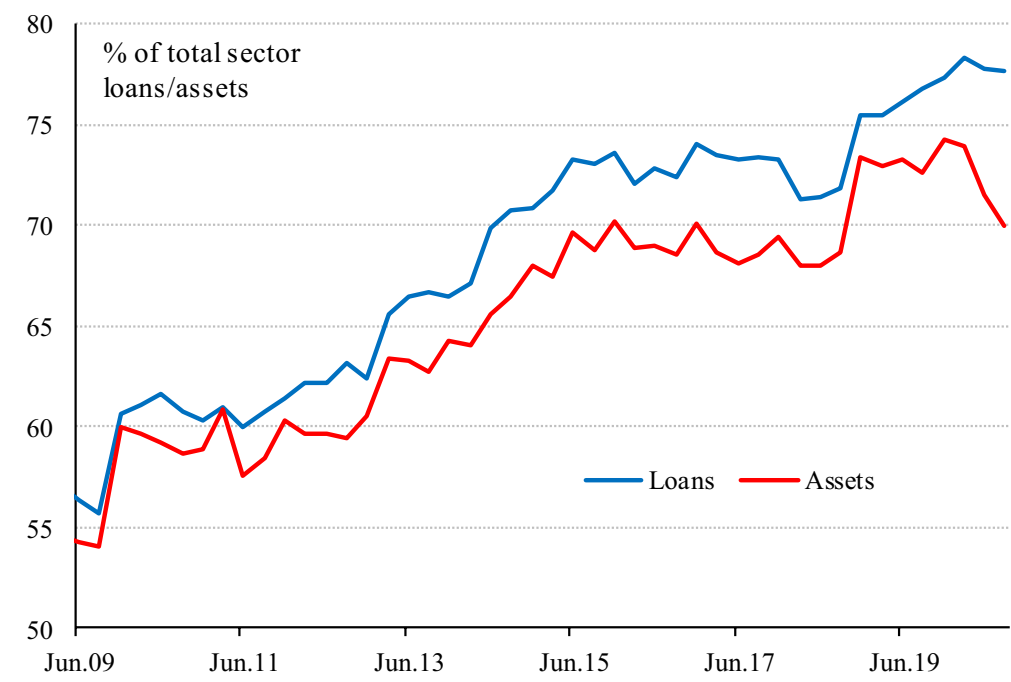

Stock Exchange ${ }^{4}$ (PKO Bank Polski, Santander, Pekao, mBank, ING, BNP Paribas (Bank Gospodarki Żywnościowej before the merger), Millennium, Getin Bank, Citibank Handlowy, Alior Bank, and Bank Ochrony Środowiska). The main reasons for the selection of the above mentioned banks were the availability of data, as well as the role played by these institutions in the Polish banking sector, described in the next paragraph. The unique microdataset comes from banks' investors relations' public databases, as well as from consolidated financial statements. The main advantages of the data are their disaggregation, as well as a detailed nature allowing for a more thorough analysis. On the other hand, a possible limitation might be related to the subsequent (that is happening after the publication date of the financial statement) changes/corrections, which have only been considered in case of the biggest banks that provide entire datasets in xlsx format. Furthermore, as Polish banking sector comprised of 563 banks as of end of 3q2020, there is a very big number of smaller (mostly less regulated) banks that have not been included in the study. The survivorship bias might also be of an issue, as the sample consists only of the stocklisted banks which have been active as of January 2021. As shown, in Fig. 1, however, they were responsible for the vast majority of banking business in Poland, throughout the entire sample period. We decided to use consolidated

\footnotetext{
Footnote 3 (continued)

delayed (by 2 quarters), which, given the first differences approach to panel GMM, draws the entire sample back as far as to the $2 \mathrm{q} 2009$.

4 The main reason behind using the data for the stock-listed companies is their availability. The Author did not have access to the publicly unavailable data from the central bank or financial supervisor. The sample includes one state owned bank (Bank Ochrony Srodowiska) and three state controlled ones (PKO Bank Polski, Pekao, and Alior Bank).
}

data for banking groups due to the role of their mortgage and leasing subsidiaries in financing the nonfinancial sector, which would not be included if the individual financial statements were used as a unique source of information. The choice of the starting data allows us to avoid the impact of GFC on bank lending. A similar set of banking data (from a different source and a different time period, though), has been used by Kapuściński [39], who showed that a weaker balance sheet leads to a smaller response of bank lending to a monetary policy impulse.

The (micro) banking group sample includes different types of banks (from those focusing to a large degree on retail banking, through those with a heavier focus on corporate financing to one that invests heavily in securities, see Table 1). The covered banks hold $70.0 \%$ of total banking sector assets, and $77.3 \%$ of lending volume as of end-September 2020 (see Fig. 1). They also have 75.0\% of sectors own funds, and (only) $53.0 \%$ of free lending capacity (both as of end-September 2020) proving that the bigger banks are more tightly regulated in Poland (which is true, due to i.a. the OSII buffer, as well as bank-specific FX-risk capital add-on).

Table 1 contains some basic indicators allowing for a qualitative analysis of the analysed bank sample. It points at a heterogeneity among the banks listed on the WSE. The sample itself is fairly well diversified in relation to the market average, as regards: ROE, share of corporate and retail loans, as well as capital position. The level of capitalisation differs among the banks. The sample includes both well-capitalised banks, as well as those which have problems with the fulfilment of the regulatory requirements. Our panel is unbalanced, as some of the banks that are listed on the WSE were established during the analysed period. Others, despite being older, have been enlisted during the studied period and do not offer older data. 


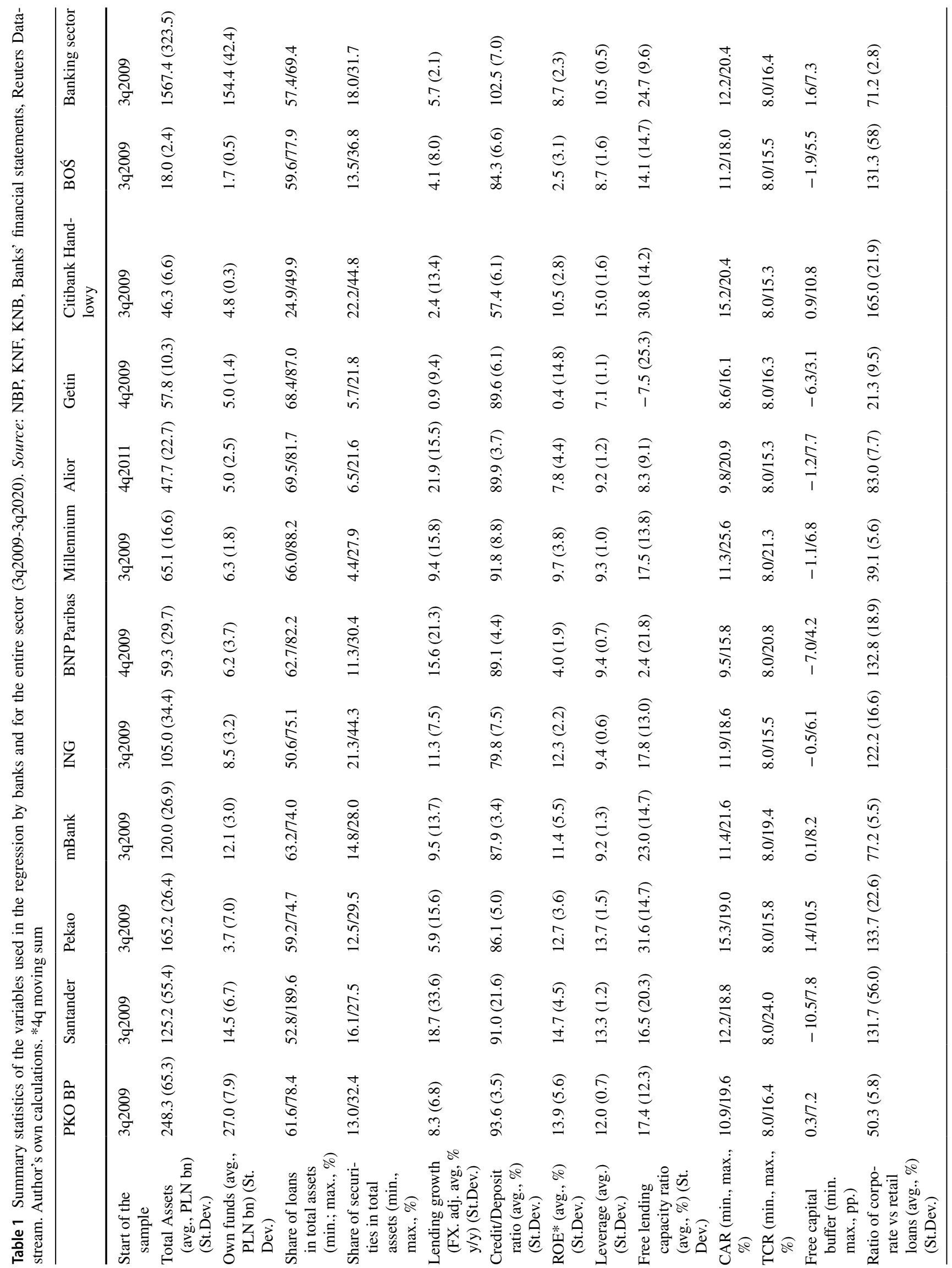

望: 
In our empirical analysis, we explain changes in the dynamics of bank lending growth. That said, we use two measures of lending: credit to the nonfinancial sector, as well as total credit. As we try to explain the impact of capital regulation on bank lending activity we use several measures of regulatory capital stringency, including the earlier described free capital buffer, free capital ratio, and free lending capacity ratio. We also employ a simple leverage ratio defined as the quotient of regulatory capital and unweighted assets to verify, if the risk weighting has an important explanatory power in relation to bank lending.

We control the impact of the above variables using the most important (and basic) measures related to credit demand: GDP growth (both nominal and real), as well as real interest rate (deflated using the current local CPI inflation). That said, we use two measures of nominal interest rates: 3-month WIBOR which is the most commonly used reference rate in Polish loan contracts, and the weighted average of 3-month WIBOR, LIBOR EUR, LIBOR CHF, and LIBOR USD, weighting them by the share of the respective currency in individual bank's loan portfolio. Both control variables proxy for lending demand, changing along economic activity (phase of the business cycle) and depending on the (real) cost of credit. Table 2 displays the sources of the data used in the model estimations.

Due to a significant role of FX loans in the lending activity of Polish banks, we decided to adjust the changes in bank lending volume for movements of FX rates of the 3 most important currencies (CHF, EUR, and USD). ${ }^{5}$ It allows us to control for situations, when changes in lending volume (in PLN) are driven by FX movements. As the banks usually do not publish the currency structure of their lending portfolio on a quarterly basis (they mostly show it in annual reports), we use the end of year data and approximate the shares throughout the year assuming a linear pattern in their changes between the ends of consecutive years.

Finally, as during the 11-year period under observation banks engaged in 9 (big) mergers and acquisitions processes, it is vital to account for their impact on the respective lending volumes. ${ }^{6}$ To do that, we gather information on the value of total loans of both merging entities, add it up and measure the change of this value to what has been posted in the first combined statement. In case when only a part of a bank was acquired, we distinguish this chunk using information contained in the financial statements. The quarterly change resulting from this calculation replaces the original

\footnotetext{
5 Doing that, we followed the currency structure of individual bank's loan portfolio.

${ }^{6}$ Not accounting for the M\&As (at first glance) does not significantly change the findings, however weakens their meaningfulness, as the $\mathrm{y} / \mathrm{y}$ dynamics skyrockets during the entire year following a merger.
}

(disturbed) value. As a last step, we calculate the annual growth rate as the product of four consecutive quarterly changes.

Descriptive statistics for the variables used in the estimations are reported in Table 3. For each variable, the measures of central tendency as well as the total number of observations are shown. All the variables are stationary (as underlined by the augmented Dickey-Fuller tests' results) and follow a normal distribution (as indicated by the results of Jarque-Bera tests).

\section{Empirical analysis: stylised facts and model estimations}

In this section, we provide the description and evaluation of our models. We start, by a short introduction to changes to capital requirements in Poland (in general), as well as the qualitative analysis of the measures of macroprudential policy tightness.

\section{Changes to capital requirements in Poland}

2012 marks a visible shift in Polish (macro)prudential supervision. In late 2011, the President of the KNF started sending letters to banks' CEOs urging them to have higher (than usual 8\% TCR) CARs (by a factor of $4 \mathrm{pp}$.) in order to be allowed to pay dividends. Although the letters were not binding according to the Polish law, the authority, position of the KNF, as well as fear of more frequent and stricter supervisory controls resulted in a permanent shift of banks behaviour. These letters have been sent until 2017, when the "dividend buffer" was legally sanctioned and reduced to $1.5 \%$ (starting from 2018), due to the introduction of an official 3\% systemic risk buffer. Earlier on (in Autumn) 2015 the KNF introduced the 3rd Pillar (individual) capital add-ons for the risk of FX mortgages held by some banks (they were subsequently changed on a yearly basis). At the same time, a new Banking Law has been passed by the Parliament implementing the new CRD IV/CRR regime in Poland. Starting from 2016 the capital conservation buffer has been introduced (with a transitory period up to 2019). In 2017, other significant financial institutions buffers were implemented by the KNF and Financial Stability Committee (the new Polish macroprudential body), and have been adjusted (in level and addressee) henceforth. In response to the outbreak of the COVID-19-related recession, the Ministry of Finance has abolished the systemic buffer on the recommendation of the Financial Stability Committee. All of the above changes point at an active use of capital regulation in the pursue of the goal of financial stability. At the very same 
Table 2 Variables and their sources

\begin{tabular}{ll}
\hline Variable & Source \\
\hline Bank credit to nonfinancial sector & Banks' consolidated financial statements \\
Total bank credit & Banks' consolidated financial statements \\
Nominal GDP & GUS (StatOffice) \\
Real GDP & GUS (StatOffice) \\
CPI inflation & GUS (StatOffice) \\
WIBOR 3 M & Reuters Eikon \\
LIBOR 3 M USD & Reuters Eikon \\
LIBOR 3 M CHF & Reuters Eikon \\
LIBOR 3 M EUR & Reuters Eikon \\
Bank credit currency structure & Banks' consolidated financial statements \\
Total capital ratio & Banks' consolidated financial statements \\
Total capital requirement (incl. all buffers, own calc.) & CRR, Financial Stability Committee, KNF, \\
& Polish Press Agency (PAP)—-banks' ESPI \\
Leverage ratio (regulatory capital to total assets, own calc.) & reports \\
Average asset risk weight (total risk exposure, assets, own calc.) & Banks' consolidated financial statements \\
\hline
\end{tabular}

Table 3 Descriptive statistics

\begin{tabular}{lrrrrrrrr}
\hline & Mean & Median & Max & Min & Std. Dev & $\begin{array}{l}\text { Jarque- } \\
\text { Bera } \\
\text { (prob.) }\end{array}$ & $\begin{array}{l}\text { ADF (prob.) } \\
\text { Obs }\end{array}$ \\
\hline Credit to nonfinancial sector $(y / y)$ & & & & & & & & \\
Total credit $(y / y)$ & 6.91922 & 6.04736 & 43.28329 & -17.32870 & 8.83414 & 0.000 & 0.000 & 469 \\
Real GDP $(y / y)$ 1st derivative & 6.50799 & 6.04383 & 39.68496 & -27.98789 & 8.81533 & 0.000 & 0.000 & 469 \\
Nominal GDP $(y / y)$ 1st derivative & -0.00059 & 0.00079 & 0.06650 & -0.09668 & 0.01986 & 0.000 & 0.000 & 495 \\
Real weighted interest rate $(q / q)$ 1st derivative & -0.00045 & 0.00068 & 0.07653 & -0.09622 & 0.02243 & 0.000 & 0.000 & 495 \\
Real 3 M WIBOR $(q / q)$ 1st derivative & -0.00083 & 0.00029 & 0.01378 & -0.01212 & 0.00636 & 0.002 & 0.000 & 495 \\
Free capital buffer & 0.02609 & 0.02237 & 0.10806 & -0.07045 & 0.02916 & 0.000 & 0.066 & 484 \\
Free capital ratio & 0.16080 & 0.14469 & 0.57460 & -0.63200 & 0.19407 & 0.000 & 0.080 & 484 \\
Free lending capacity ratio & 0.25906 & 0.16915 & 1.35072 & -0.38633 & 0.31229 & 0.000 & 0.049 & 484 \\
Leverage ratio & 0.10079 & 0.10156 & 0.13872 & 0.06226 & 0.01612 & 0.049 & 0.006 & 484 \\
\hline
\end{tabular}

time, banks responded to the regulatory changes, either by cutting their lending or adjusting the level of capital (issuing Tier II debt or retaining earnings). In the meantime, some important adjustments have been made to the risk weighting system, including first of all the imposition of a $150 \%$ risk weight for FX denominated mortgage loans (May 2017) and lower risk weights related to the implementation of CRR COVID-19 QuickFix. Figure 2 depicts the fluctuations in the TCR, FLCR, CAR as well as banks responses (in terms of lending) to the regulatory changes.

\section{Measures of bank-specific capital position}

As indicated above, the capital position and free capital buffer of banks in Poland varied over time. It should be underlined, however, that these variations touched different banks to a different extent, as for example cooperative banks (responsible for app. 10\% of the banking sector) were much less burdened than commercial (and first of all biggest, stock listed) banks. Among the latter, which are in the focus of our the empirical study the capital position, as well as regulatory space for lending expansion also differed a lot, as shown in Fig. 3.

Figure 3 underpins the heterogeneity of the studied banks, as capital adequacy is concerned: there are visible shifts (cycles) of three key explanatory variables (free capital 
Fig. 2 Measures of banking sector's capital adequacy vs. total loan growth (quarterly data) in Poland (2005-2020). Source: NBP, KNF, KNB, CRR, Financial Stability Committee, KNF, Polish Press Agency (PAP)—banks' ESPI reports, Reuters Datastream. Author's own calculations

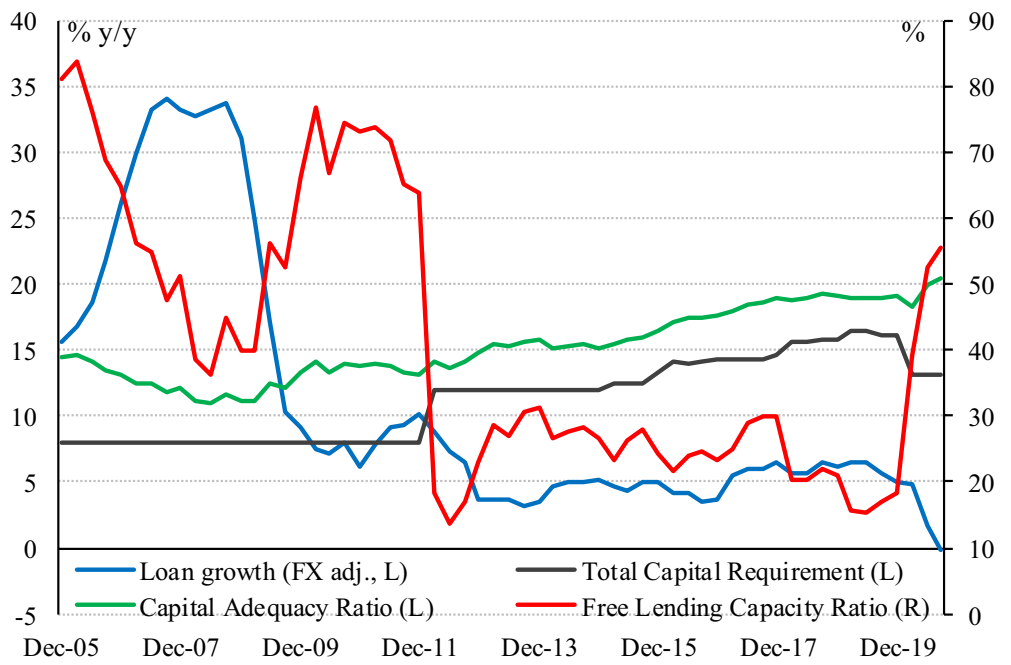

buffer, free capital ratio, as well as free lending capacity ratio), which result from common changes in capital requirements. However, due to a different model of banking, ability to build up capital over time (for example, via retained earnings), and the approach to quantify risk (four banks use internal ratings to calculate capital requirements for retail or corporate portfolio) the impact of these shifts on the capacity to expand lending varies in the sample. Moreover, some banks (for example, \#8 and \#9) managed to rebuild their capital position, thanks to recapitalisation, and revised lending strategy. The three variables share a common factorfree capital buffer-resulting in the fact that they all change signs at once, meaning that they all simultaneously indicate when a bank does not fulfil the (adjusted) capital require- where the subscripts of $i$ and $t$ denote bank and time period, respectively. $\Delta$ Loans is the annual change of FX adjusted volume of loans to the nonfinancial sector, whilst $X$ is the vector of explanatory variables (one period lagged changes in annual GDP growth rate, as well as a change in inflationadjusted (real) interest rate); $\mathrm{LC}$ is a measure of lending capacity/macroprudential policy tightness, in our case either the free capital buffer (FCB), free capital ratio (FCR), free lending capacity ratio (FLCR), or the leverage ratio; $\mu$ is the bank-specific effect, and $\varepsilon$ is the error term.

The GMM panel estimators have the ability to control for time series and cross-sectional variation in data. Moreover, this method eliminates bank-specific effect problem by differentiating the regression equation:

$\Delta$ Loans $_{i, t}-\Delta$ Loans $_{i, t-1}=\alpha \times\left(\Delta\right.$ Loans $_{i, t-1}-\Delta$ Loans $\left._{i, t-2}\right)+\beta \times\left(X_{i, t-n}-X_{i, t-n-1}\right)+\gamma \times\left(L C_{i, t-2}-L C_{i, t-3}\right)+\left(\varepsilon_{i, t}-\varepsilon_{i, t-1}\right)$.

ments. They are also correlated with the average (among the 11 banks) Pearson coefficients at: 0.9578 (FLCR vs. FCB), 0.9817 (FLCR vs. FCR), and 0.9810 (FCB vs. FCR). As follows, we present the model specification, discussion of the econometric methods, and estimation results. At the end, we check the robustness of our estimates.

\section{Model specification and results}

To assess the relationship between capital regulation and bank lending, we utilise the Generalised Method of Moments (GMM) estimators for panel data models, which are widely applied in economic literature including the earlier discussed works on the evaluation of macroprudential policy effectiveness. The model specification is presented below:

$\Delta$ Loans $_{i, t}=\alpha \times \Delta$ Loans $_{i, t-1}+\beta \times X_{i, t-n}+\gamma \times L C_{i, t-2}+\mu_{i}+\varepsilon_{i, t}$
As Eq. (7) introduces a correlation between the new error term and the lagged dependent variable, we employ the (two-step) Arellano and Bond [8] first difference GMM estimator with multiple lagged values of the explanatory variables as instruments.

It should be underlined that it is recommended to perform a model with panel data, when the sample is characterised by a large number of individuals $(N)$ and a small period of time $(T)$. It is not our case, however, as $N=11$, whilst $T=47$. Such long panel requires a more careful approach, due to a bigger likelihood of the proliferation of instruments and serial autocorrelation of errors leading to a high probability of overidentification (Roodman [50], Labra and Torrecillas [42]). In order to avoid this problem, the number of individuals (or groups) must be greater than the number of instruments used. Therefore, in our case, the small number of banks in the sample demands a reduction of the number of instruments. To achieve that, we (1) reduce the number 

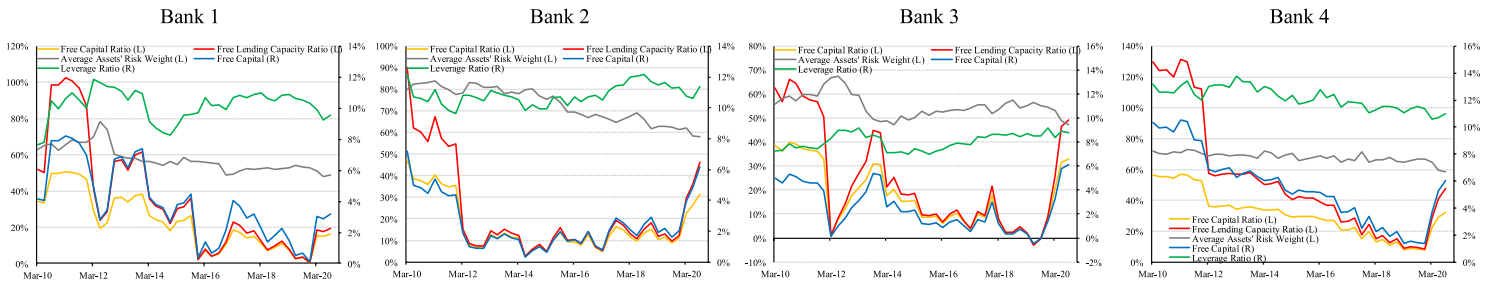

Bank 5

Bank 6

Bank 7

Bank 8

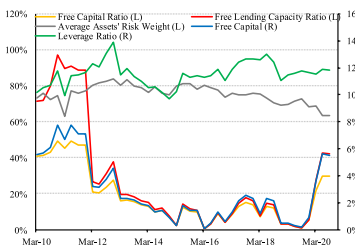

Bank 9

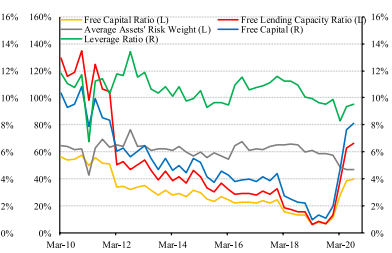

Bank 10
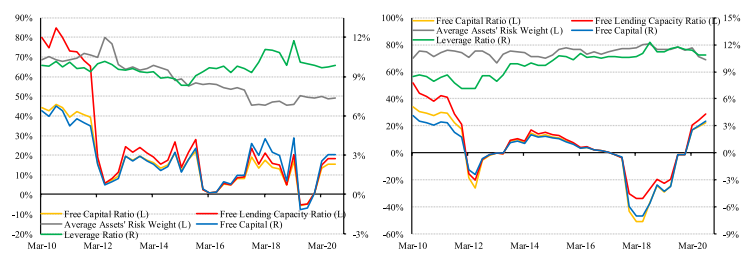

Bank 11
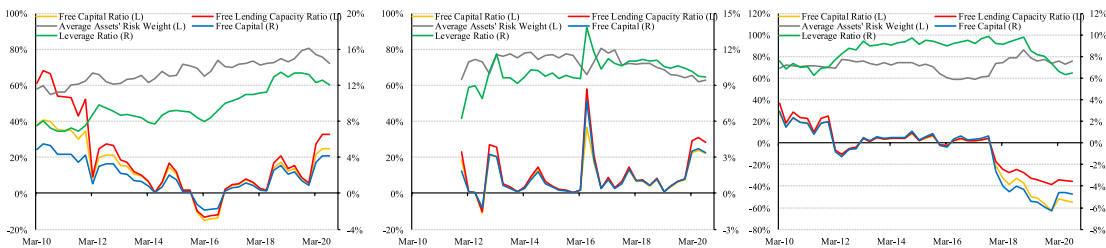

Fig. 3 Bank-specific different measures of regulatory stringency (2010-2020). Source: Bank consolidated financial statements, CRR, Financial Stability Committee, KNF, Polish Press Agency (PAP)—banks' ESPI reports

of explanatory variables and (2) restrict the number of lags (in instruments) to two. Secondly, as we face the endogeneity problem (explaining bank lending by banks internal feature-ability to expand credit) we use a two-period lagged explanatory variable (FCB, FCR, FLCR, leverage ratio). From practical point of view, such a decision makes sense, as banks finalise the financial plan for each quarter in the previous one (one period lag), but they do not know their lending capacity yet, as the period is not over. That said, when they issue targets for their sales departments, they need to follow a two-period delayed capacity to expand lending. The first difference GMM estimator that uses only the lags of differences as instruments gives us additional advantage in the reduction of the number of instruments in comparison to the system GMM (Arellano and Bover [9]) that uses lags in differences and levels (in the robustness analysis, we present the results of a system GMM model with a reduced number of lags to show the similarity of the results).

Another important issue is the unbalanced character of our data, which usually prevents the use of a differenced GMM approach, due to gaps in the data series. It is not our case, however, as the imbalance of our sample results from different starting point of the data in some series, whereas the problem of gaps is non-existent. We also tested the instrument variables for serial autocorrelation, using Arellano and Bond test (verifying if the probability of $\operatorname{AR}(2)(\operatorname{pr}>z)$ is higher than 5\%). To verify the validity of the instruments used in the analysis we utilise Hansen Test which is recommended to use with the heteroscedastic weight matrix (two-step). It should be emphasised that according to Roodman [50] the probability in this test should not only be higher than 5\%, but also not close to $100 \%$ (recommended values lie between 10 and 25\%).

The results of our baseline estimations are presented in Table 4 (yy stands for the annual change of the variable).

All the models point at a strong (all the time statistically significant) positive relation between real GDP growth and credit growth, meaning that the demand may play important role in explaining the size of the lending expansion. As the changes in FX weighted real interest rates are not statistically significant, we cannot draw any binding conclusions from these results, although the sign of their impact on lending seems to be in line with our intuition as rising rates imply lower borrowers demand for credit. Finally, the measures of capital adequacy display promising results. All the three variables representing the impact of macroprudential regulation show a strong (or very strong in case of FLCR) positive relation with lending expansion, in line with our expectations and similar to the results found in economic literature. That said, a bigger capital space for credit extension results in the acceleration of lending growth. The relation between the leverage ratio and lending is not only very week, but also counterintuitive. It is likely due to the fact that it has not been a binding instrument in the use of the regulator.

As the sample period spans over the COVID-19 recession, the results might have been impacted by a sharp decrease in demand for new lending resulting from the lockdown. On the other hand credit holidays announced by Polish banks 
Table 4 The drivers of annual changes in bank lending to the nonfinancial sector. Source: Author's own calculations

\begin{tabular}{|c|c|c|c|c|c|}
\hline \multirow{2}{*}{$\frac{\text { Dataset }}{\Delta \text { Loans }(\mathrm{yy})_{t-1}}$} & \multirow{2}{*}{$\frac{\text { Time lag }}{-1}$} & \multicolumn{4}{|c|}{ Dependent variable: $\Delta$ Loans (nonfinancial sector, yy) } \\
\hline & & $0.7242 * * *(0.0190)$ & $0.7156 * * *(0.0186)$ & $0.7071 * * *(0.0213)$ & $0.7598 * * *(0.0231)$ \\
\hline $\begin{array}{l}\left(100+\Delta \text { GDP_real_yy }{ }_{t}\right) / \\
\quad\left(100+\Delta \text { GDP_real_yy }{ }_{t-1}\right)-1\end{array}$ & -1 & $40.2046 * * *(14.2874)$ & $40.67 * * *(15.0370)$ & $37.6315^{* * *}(14.4182)$ & $34.1599 * *(15.6043)$ \\
\hline $\begin{array}{l}(100+\text { real_FXweighted_IRate }) / \\
(100+\text { real_FXweighted_IRa- } \\
\left.t_{t-1}\right)-1\end{array}$ & 0 & -181.1385 (144.8786) & -171.3815 (142.1639) & $-171.3556(147.6872)$ & $-168.0142(128.0170)$ \\
\hline Free capital buffer & -2 & $78.292 * *(34.8636)$ & & & \\
\hline Free capital ratio & -2 & & $10.6713 * *(5.3292)$ & & \\
\hline Free lending capacity ratio & -2 & & & $8.1304 * * *(2.8258)$ & \\
\hline Leverage ratio & -2 & & & & $-12.1518(31.5279)$ \\
\hline \multicolumn{6}{|l|}{ Cross sections fixed (first differences) } \\
\hline No. of observations & & 447 & 447 & 447 & 447 \\
\hline Serial correlation test (1) & & 0.111 & 0.100 & 0.248 & 0.073 \\
\hline Hansen test (2) & & 0.269 & 0.258 & 0.281 & 0.245 \\
\hline
\end{tabular}

$* * *, * *, *$ Significance at $1 \%, 5 \%$, and $10 \%$ test levels, respectively; standard errors are in parentheses. All explanatory variables have been included as instrument variables with two lags. White period instrument weighting matrix. White period standard errors \& covariance (no d.f. correction). Constant added to instrument list. (1) Reports $p$ values for the null hypothesis that the errors in the first difference regression exhibit no second-order serial correlation. (2) Reports $p$ values for the null hypothesis that the instruments used are not correlated with the residuals

meant that some of the borrowers (mostly enterprises) could withhold loan repayment. Given the small size of the sample, modelling the studied interdependencies in the time of the pandemic would not yield materially relevant results. However, it should be underlined that the exclusion of the last 2 quarters from the sample does not materially impact the results.

\section{Robustness checks}

We conduct a series of checks to verify the sensitivity of our benchmark results. The number of checks is increased to improve the relevance of the results ${ }^{7}$ that could be undermined by a small size of the sample. We start by changing the dependent variable. That said we use (1) annual changes to FX adjusted total credit (loans to nonfinancial sector plus loans to financial sector). As credit growth can follow some structural patterns in the medium/long run, for instance slow down to the satiation of the market with debt, we also see if (2) the lending capacity has any impact on the deviations of lending growth from its trend (measured using HP filter with lambda set at $1600^{8}$ ). In the latter case, we adapt the GDP growth measure to follow the changes in the deviation of GDP growth from its trend (HP filtered using lambda $=1600)$. The results are presented in Tables 5 and 6.

\footnotetext{
${ }^{7}$ Along with the choice of the sample (public listed banks), as well as selection of the econometric methods, as described in previous sections.

${ }^{8}$ As suggested for quarterly data by Hodrick and Prescott [36].
}

Subsequently, we (3) change the controlling variables in our sample, that is switch real to nominal GDP growth, and CPI deflated weighted interest rate to CPI deflated WIBOR $3 \mathrm{M}$. As we do not include inflation in the panel of explanatory variables, the nominal GDP growth may actually better reflect the impact of changing prices (on the top of the expansion of real demand) on the growth of lending (which is also calculated in nominal terms). The switch from (currency) weighted market interest to WIBOR $3 \mathrm{M}$ (Polish interbank market lending rate) is motivated by the rising share of local currency loans in new lending, following supervisory recommendations aimed at curbing the expansion of FX mortgage loans (Table 7).

Last but not least, we decrease the number of lags of instruments to 1 and (4) employ the system GMM for our initial model. In this case, the reduction of the number of lags to one allows us to maintain the number of instruments below the number of cross sections (banks) (Table 8).

The robustness tests confirm our earlier results, pointing at a positive relation between banks' capital adequacy and their lending expansion. Interestingly, the FLCR remains statistically significant throughout all the checks, whereas other "core" variables (FCB and FCR) loose their significance but remain positively correlated with the dependent variable. The reason (along with the explanation for their lower statistical significance (than the FLCR) in all the previous models) might be the construction of each variable, allowing (in case of the FLCR) to take into account the changes of the capital requirements not only as the factor limiting the available (free) own funds, but also constraining the use of this surplus capital as a basis for the expansion 
Table 5 The drivers of annual changes in total bank lending. Source: Author's own calculations

\begin{tabular}{|c|c|c|c|c|c|}
\hline \multirow{2}{*}{$\frac{\text { Dataset }}{\Delta \text { Loans }(\mathrm{yy})_{t-1}}$} & \multirow{2}{*}{$\frac{\text { Time lag }}{-1}$} & \multicolumn{4}{|c|}{ Dependent variable: $\Delta$ Loans (total, yy) } \\
\hline & & $0.5956 * * *(0.0556)$ & $0.5872 * * *(0.0657)$ & $0.5823 * * *(0.0416)$ & $0.6739 * * *(0.1777)$ \\
\hline $\begin{array}{l}\left(100+\Delta \text { GDP_real_yy }{ }_{t}\right) / \\
\left(100+\Delta \text { GDP_real_yy }{ }_{t-1}\right)-1\end{array}$ & -1 & $40.4694 * * *(13.7632)$ & $40.8658 * * *(14.5815)$ & $38.8362 * * *(12.4813)$ & $37.9461 *(19.5288)$ \\
\hline $\begin{array}{l}(100+\text { real_FXweighted_IRate }) / \\
(100+\text { real_FXweighted_IRa- } \\
\left.t_{t-1}\right)-1\end{array}$ & 0 & $-93.8521(91.9115)$ & $-103.254(89.7157)$ & $-68.5311(82.8324)$ & $-212.2053 *(120.7548)$ \\
\hline Free capital buffer & -2 & $79.0995 * * *(25.1426)$ & & & \\
\hline Free capital ratio & -2 & & $13.8982 * *(5.8998)$ & & \\
\hline Free lending capacity ratio & -2 & & & $9.4892 * * *(2.1644)$ & \\
\hline Leverage ratio & -2 & & & & $-20.9887(55.9161)$ \\
\hline \multicolumn{6}{|l|}{ Cross sections fixed (first differences) } \\
\hline No. of observations & & 447 & 447 & 447 & 447 \\
\hline Serial correlation test (1) & & 0.145 & 0.212 & 0.112 & 0.236 \\
\hline Hansen Test (2) & & 0.331 & 0.296 & 0.341 & 0.293 \\
\hline
\end{tabular}

$* * *, * *$ *Significance at $1 \%, 5 \%$, and $10 \%$ test levels, respectively; standard errors are in parentheses. All explanatory variables have been included as instrument variables with two lags. White period instrument weighting matrix. White period standard errors \& covariance (no d.f. correction). Constant added to instrument list. (1) Reports $p$ values for the null hypothesis that the errors in the first difference regression exhibit no second-order serial correlation. (2) Reports $p$ values for the null hypothesis that the instruments used are not correlated with the residuals

Table 6 The drivers of the deviations of credit growth from its trend. Source: Author's own calculations

\begin{tabular}{|c|c|c|c|c|c|}
\hline \multirow{2}{*}{$\frac{\text { Dataset }}{\Delta \text { Loans }(\mathrm{yy})_{t-1}-\operatorname{Trend}(\mathrm{yy})_{t-1}}$} & \multirow{2}{*}{$\begin{array}{l}\text { Time lag } \\
-1\end{array}$} & \multicolumn{4}{|c|}{ Dependent variable: $\Delta$ Loans (total, yy) - Trend(yy) } \\
\hline & & $0.7927 * * *(0.0684)$ & $0.7783^{* * *}(0.0477)$ & $0.7876^{* * * *}(0.0677)$ & $0.7651^{* * * *}(0.0286)$ \\
\hline$\Delta \mathrm{GDP} \_r e a l \_\mathrm{yy}_{t-1}-\operatorname{Trend}(\mathrm{yy})_{t-1}$ & -1 & $0.2939(0.4234)$ & $0.2921(0.3882)$ & $0.2461(0.3995)$ & $0.2836(0.2852)$ \\
\hline $\begin{array}{l}(100+\text { real_FXweighted_IRa- } \\
\left.\text { te }_{t}\right) /(100+\text { real_FXweighted_ } \\
\left.\text { IRate }_{t-1}\right)-1\end{array}$ & 0 & $-160.4042 * *(65.1079)$ & $-173.4041 * * *(59.1946)$ & $-152.4006^{* * *}(53.7440)$ & $-219.9727^{* * *}(53.7991)$ \\
\hline Free capital buffer & -2 & $168.3459 *(94.1259)$ & & & \\
\hline Free capital ratio & -2 & & $25.6915 *(15.2639)$ & & \\
\hline Free lending capacity ratio & -2 & & & $14.5966 * *(7.2940)$ & \\
\hline Leverage ratio & -2 & & & & $191.8565 *(100.0274)$ \\
\hline \multicolumn{6}{|c|}{ Cross sections fixed (first differences) } \\
\hline No. of observations & & 447 & 447 & 447 & 447 \\
\hline Serial correlation test (1) & & 0.150 & $0.038^{\wedge}$ & 0.245 & 0.108 \\
\hline Hansen Test (2) & & 0.480 & 0.466 & 0.450 & 0.419 \\
\hline
\end{tabular}

$* * *, * *, *$ Significance at $1 \%, 5 \%$, and $10 \%$ test levels, respectively; standard errors are in parentheses. All explanatory variables have been included as instrument variables with two lags. White period instrument weighting matrix. White period standard errors \& covariance (no d.f. correction). Constant added to instrument list. (1) Reports $p$ values for the null hypothesis that the errors in the first difference regression exhibit no second-order serial correlation. (2) Reports $p$ values for the null hypothesis that the instruments used are not correlated with the residuals

${ }^{\wedge}$ The probability is too low, pointing at a second-order serial correlation

of lending. It is worth noting that changes to real interest rate significantly (and negatively) impact credit growth in case of total credit, as the explanatory variable. It may well mean that the credit to financial institutions depends to a bigger extent on interest rates than on GDP growth, as the latter looses significance in the described model. Finally, it is worth noting that in the case of the model explaining deviations of lending growth from its trend, the leverage ratio turned out to be statistically significant with an intuitive, positive impact on the dependent variable. It can mean that the ratio does not impact the pace of the credit expansion itself, but underlie the aggressiveness of the lending strategy. For example, a bank may decide to expand lending following its competition, but having a more conservative leverage ratio, may well increase its capital (and space) to grow faster and increase the market share.

That said, one swallow does not a summer make, and we cannot conclude that the leverage ratio is a driver of changes to bank lending, as other models do point neither at its significance, nor at an unequivocal direction of its impact. On 
Table 7 The drivers of annual changes in bank lending to the nonfinancial sector (second set of controlling variables). Source: Author's own calculations

\begin{tabular}{|c|c|c|c|c|c|}
\hline \multirow{2}{*}{$\frac{\text { Dataset }}{\Delta \text { Loans }(\mathrm{yy})_{t-1}}$} & \multirow{2}{*}{$\frac{\text { Time lag }}{-1}$} & \multicolumn{4}{|c|}{ Dependent variable: $\Delta$ Loans (nonfinancial sector, yy) } \\
\hline & & $0.6766^{* * *}(0.0527)$ & $0.6547 * * *(0.0572)$ & $0.6697 * * *(0.0462)$ & $0.6638 * * *(0.0606)$ \\
\hline $\begin{array}{l}\left(100+\Delta \mathrm{GDP} \_n o m \_y y_{t}\right) / \\
\left(100+\Delta \mathrm{GDP} \_n o m \_\right. \\
\left.\mathrm{yy}_{t-1}\right)-1\end{array}$ & -1 & $92.4955 * * *(34.3161)$ & $103.1553 * * *(35.5564)$ & $85.1638 * *(33.1814)$ & $110.5874 * * *(36.0480)$ \\
\hline $\begin{array}{l}\left(100+\text { real_WIBOR }_{\mathrm{t}}\right) / \\
\left(100+\text { real_}_{-}\right. \\
\left.\text {WIBOR }_{t-1}\right)-1\end{array}$ & 0 & $-361.824 *(209.7017)$ & $-392.6185^{*}(203.9414)$ & -335.0905 (211.9459) & $-458.5482 * *(184.7317)$ \\
\hline Free capital buffer & -2 & $55.2253(40.5022)$ & & & \\
\hline Free capital ratio & -2 & & $5.0782(8.0653)$ & & \\
\hline Free lending capacity ratio & -2 & & & $6.3849 * *(3.1359)$ & \\
\hline Leverage ratio & -2 & & & & $-41.6601(52.1978)$ \\
\hline \multicolumn{6}{|c|}{ Cross sections fixed (first differences) } \\
\hline No. of observations & & 447 & 447 & 447 & 447 \\
\hline Serial correlation test (1) & & 0.181 & 0.190 & 0.572 & 0.130 \\
\hline Hansen test (2) & & 0.411 & 0.452 & 0.399 & 0.548 \\
\hline
\end{tabular}

$* * *, * *, *$ Significance at $1 \%, 5 \%$, and $10 \%$ test levels, respectively; standard errors are in parentheses. All explanatory variables have been included as instrument variables with two lags. White period instrument weighting matrix. White period standard errors $\&$ covariance (no d.f. correction). Constant added to instrument list. (1) Reports $p$ values for the null hypothesis that the errors in the first difference regression exhibit no second-order serial correlation. (2) Reports $p$ values for the null hypothesis that the instruments used are not correlated with the residuals

Table 8 The drivers of annual changes in bank lending to the nonfinancial sector (System GMM). Source: Author's own calculations

\begin{tabular}{|c|c|c|c|c|c|}
\hline \multirow{2}{*}{$\frac{\text { Dataset }}{\Delta \text { Loans }(\mathrm{yy})_{t-1}}$} & \multirow{2}{*}{$\frac{\text { Time lag }}{-1}$} & \multicolumn{4}{|c|}{ Dependent variable: $\Delta$ Loans (nonfinancial sector, yy) } \\
\hline & & $0.8173 * * *(0.0380)$ & $0.8127 * * *(0.0356)$ & $0.8199 * * *(0.0380)$ & $0.8621 * * *(0.0348)$ \\
\hline $\begin{array}{l}(100+\Delta \text { GDP_real_yy }) / \\
(100+\Delta \text { GDP_real_ } \\
\left.\mathrm{yy}_{t-1}\right)-1\end{array}$ & -1 & $0.2886(1.2538)$ & $0.1977(1.2475)$ & $0.2916(1.2549)$ & $-0.0297(1.3452)$ \\
\hline $\begin{array}{l}(100+\text { real_FXweighted_ } \\
\left.\text { IRate }_{t}\right) /(100+\text { real_ } \\
\text { FXweighted_IRa- } \\
\left.\text { te }_{t-1}\right)-1\end{array}$ & 0 & $-237.8733 * * *(90.0053)$ & $-237.3346 * * *(91.0056)$ & $-234.3636^{* *}(91.2351)$ & $-194.7571 *(104.8230)$ \\
\hline Free capital buffer & -2 & $33.5727 * * *(10.4831)$ & & & \\
\hline Free capital ratio & -2 & & $4.1427 * * *(1.0935)$ & & \\
\hline $\begin{array}{l}\text { Free lending capacity } \\
\text { ratio }\end{array}$ & -2 & & & $2.3906 * * *(0.7250)$ & \\
\hline Leverage ratio & -2 & & & & $1.7079(1.7329)$ \\
\hline \multicolumn{6}{|c|}{ Cross sections fixed (orthogonal deviations) } \\
\hline No. of observations & & 447 & 447 & 447 & 447 \\
\hline Hansen test (1) & & 0.309 & 0.317 & 0.307 & 0.322 \\
\hline
\end{tabular}

$* * *, * *, *$ Significance at $1 \%, 5 \%$, and $10 \%$ test levels, respectively; standard errors are in parentheses. All explanatory variables have been included as instrument variables with two lags. White period instrument weighting matrix. White period standard errors \& covariance (no d.f. correction). Constant added to instrument list. (1) Reports $p$ values for the null hypothesis that the instruments used are not correlated with the residuals

the other side of the spectrum lies the free lending capacity ratio (FLCR), the measure that we pointed out as the most convincing indicator of regulatory stringency. All the models pointed at its statistical significance, and a positive impact on banks' lending expansion.

\section{Discussion and conclusions}

Applying the micro (bank-specific) data to a macroproblem, we show that a link may exist between banks' lending capacity, and the decisions they take regarding the expansion of their lending. The most important value added we provide is 
the construction and definition of a new, promising measure of (macro)prudential policy restrictiveness. From a theoretical point of view, the free lending capacity ratio allows to include the issue of regulatory arbitrage into the analysis of macroprudential policy effectiveness. It also tackles the problem of heterogeneity within the banking sector, as it is robust to different ways of risk measurement (standardised approach vs. advanced measurement approach), as well as structure of bank business (by taking into account the risk weighting and relating the lending capacity to total volume of loans). That said, it may allow to distinguish between internal features of banks in different markets (for example, in advanced versus emerging), in particular their approach to risk measurement. From the empirical side, it proves to be a reliable explanatory factor for changes in bank lending decisions. That said, our analysis may be of an importance from the point of view of the supervisory and regulatory authorities wishing to assess the impact of their policy. It may also be relevant for monetary policymakers (particularly in a currency union), as it not only sheds light on possible nonlinearities in monetary policy transmission mechanism, but also at likely differences of bank lending channels between different countries. What is important, the calculation of the new measure does not require much of effort, as the formula is composed from the same components as free capital buffer, which has already been used in several studies found in empirical literature. Finally, the FLCR may also be helpful in evaluating the new regulatory measures, enabling to assess (simultaneously) the impact of the changes related to the implementation of Basel IV starting from 2023, that is of the floor for a capital requirement (if a non-standardised measure to calculate risk is employed), reduction of risk weights for mortgage loans, and increase in leverage ratio for the Globally Systemically Important Banks.

Being a promising measure the FLCR is not free of any flows, though. It does not account for the structure of own funds, hence, overlooks an important form of regulatory arbitrage in forms of the dilution of regulatory capital (from Tier I to Tier II instruments). This flow can be eliminated, though, if different capital ratios are applied (CET1, Tier 1 , or total capital ratio). Secondly, in our study we use simple assumptions on bank expectations, presuming that the most relevant factors will remain constant in the foreseeable future. In reality, however, banks may consider changing the structure of lending (average risk weight) to free up some capacity; issuing new capital, retaining bigger chunk of earnings, or expect changes to capital requirements. Therefore, their anticipated lending capacity at the time of granting a loan, may differ from the one they know as they decide upon goals for sales departments. Thirdly, banks may wish to maintain a voluntary capital buffer over the regulatory minimum, which was not assumed in the case of this study. Another drawback is related to our econometric analysis, which (due to a relatively small sample of banks restricting the number of controls) does not control for changes to other policies, including (among others) the introduction of the banking tax starting from early 2016 or additional charges for the bank restructuring fund from 2017 on. Therefore, drawing more binding conclusions on the impact of lending capacity on bank lending requires further empirical research. It could be either conducted from an international or a local perspective, accounting for differences between national banking sectors, as well as institutions.

Finally, our measure (the FLCR) could prove relevant from the financial supervisor's perspective. Not only does it show (in a simple manner) the ability of banks to expand credit, but also it helps to identify factors contributing to this ability, enabling for a more targeted choice of prudential instruments to address specific issues related to the ongoing stage of the financial (credit) cycle. Moreover, it should also be observed by the monetary policymakers, as it indicates the patency of the bank lending channel, being one of the most important channels of monetary policy transmission to the real economy, in particular in continental Europe, where the banks remain key financial intermediaries. With no or small free lending capacity, even big rate cuts could not translate into increased lending. Finally, as the FLCR tackles the issue of heterogeneity, it may prove useful in the Eurozone, where the differences between banks are particularly visible, not only from an international perspective, but also within each (local) sector. That said, the efficacy of the ECB's policy (at least on the communication front) could improve, if it analysed its impact through the lens of lending capacity, but also if it considered not only heterogeneity between Eurozone members, but also differences among banks functioning on a local level.

Supplementary Information The online version contains supplementary material available at https://doi.org/10.1057/s41261-021-00164-2.

Acknowledgments The author wishes to thank Sylwia Anna Domańska and two anonymous referees for their valuable comments and suggestions.

\section{References}

1. Agur, I., and M. Demertzis. 2019. Will macroprudential policy counteract monetary policy's effects on financial stability? The North American Journal of Economics and Finance 48: 65-75. https://doi.org/10.1016/j.najef.2019.01.012.

2. Aiyar, S., C.W. Calomiris, and T. Wielądek. 2014. Does macroprudential regulation leak? Evidence from a UK policy experiment. Journal of Money, Credit and Banking 46(1): 181-214. https://doi.org/10.1111/jmcb.12086.

3. Akinci, O., and J. Olmstead-Rumsey. 2018. How effective are macroprudential policies? An empirical investigation. Journal of Financial Intermediation 33: 33-57. https://doi.org/10.1016/j.jfi. 2017.04.001. 
4. Alam, Z., A. Alter, Eiseman, J., Gelos, G., Kang, H., Narita, M., Nier, E., and Wang, N. 2019. Digging deeper-evidence on the effects of macroprudential policies from a new database IMF Working Paper No. WP/19/66. https://doi.org/10.5089/97814 98302708.001

5. Altavilla, C., M. Boucinha, Holton, S., Ongena, S. 2018. Credit supply and demand in unconventional times ECB Working Paper No. 2202. https://doi.org/10.2866/290886.

6. Araujo, J., M. Patnam, Popescu, A., Valencia, F., and Yao, W. 2020. Effects of macroprudential policy: Evidence from Over 6000 estimates IMF Working Paper No. WP/20/67. https://doi. org/10.5089/9781513545400.001.

7. Arregui, N., J. Benes, Krznar, I., Mitra, S., and Santos, A. 2013. Evaluating the net benefits of macroprudential policy: A cookbook IMF Working Paper No. WP/13/167. https://doi.org/10. 5089/9781484335727.001.

8. Arellano, M., and S. Bond. 1991. Some tests of specification for panel data: Monte Carlo evidence and an application to employment equations. The Review of Economic Studies 58(2): 277-297. https://doi.org/10.2307/2297968.

9. Arellano, M., and O. Bover. 1995. Another look at the instrumental variable estimation of error-components models. Journal of Econometrics 68(1): 29-51. https://doi.org/10.1016/03044076(94)01642-D.

10. Bernanke, B.S., and C.S. Lown. 1991. The credit crunch brookings papers. Economic Activity 22(2): 205-247.

11. Berrospide, J.M., and R.M. Edge. 2010. The effects of bank capital on lending: What do we know, and what does it mean? International Journal of Central Banking 5-54. https://www.ijcb.org/ journal/ijcb10q4a2.htm.

12. Blundell-Wignall, A., and P. Atkinson. 2010. Thinking beyond Basel III: Necessary solutions for capital and liquidity. $O E C D$ Journal: Financial Market Trends 2010(1): 9-33. https://doi.org/ 10.1787/fmt-2010-5km7k9tpcjmn.

13. Borio, C., and L. Gambacorta. 2017. Monetary policy and bank lending in a low interest rate environment: Diminishing effectiveness? Journal of Macroeconomics 54(B): 217-231. https://doi. org/10.1016/j.jmacro.2017.02.005.

14. Borio, C., and H. Zhu. 2012. Capital regulation, risk-taking and monetary policy: A missing link in the transmission mechanism? Journal of Financial Stability 8(4): 236-251. https://doi.org/10. 1016/j.jfs.2011.12.003.

15. Bruno, V., I. Shim, and H.S. Shin. 2017. Comparative assessment of macroprudential policies. Journal of Financial Stability 28: 183-202. https://doi.org/10.1016/j.jfs.2016.04.001.

16. Brunnermeier, M., and Y. Koby. 2018. The reversal interest rate NBER Working Paper No. 25406. https://doi.org/10.3386/ w25406.

17. Budnik, K.B., and J. Kleibl. 2018. Macroprudential regulation in the European Union in 1995-2014: Introducing a new data set on policy actions of a macroprudential nature ECB Working Paper No. 2123. https://www.ecb.europa.eu/pub/pdf/scpwps/ecb. wp2123.en.pdf.

18. Carreras, O., E.P. Davis, and R. Piggott. 2018. Assessing macroprudential tools in OECD countries within a cointegration framework. Journal of Financial Stability 37: 112-130. https://doi.org/ 10.1016/j.jfs.2018.04.004.

19. Catalán, M., A.W. Hoffmaister, and Harun, C.A. 2017. Bank capital and lending: an extended framework and evidence of nonlinearity IMF Working Paper No. WP/17/252. https://doi.org/10. 5089/9781484325995.001

20. Cecchetti, S.G., and M. Kohler. 2014 When capital adequacy and interest rate policy are substitutes (and when they are not). International Journal of Central Banking, 205-231. https://www.ijcb. org/journal/ijcb14q3a6.pdf.
21. Cerutti, E., S. Claessens, and L. Laeven. 2017. The use and effectiveness of macroprudential policies: New evidence. Journal of Financial Stability 28: 203-224. https://doi.org/10.1016/j.jfs. 2015.10.004.

22. Cizel, J., J. Froost, A. Houben, and P. Wierts. 2019. Effective macroprudential policy: Cross-sector substitution from price and quantity measures. Journal of Money, Credit and Banking 51(5): 1209-1235. https://doi.org/10.1111/jmcb.12630.

23. Claessens, S., S.R. Ghosh, and R. Mihet. 2013. Macro-prudential policies to mitigate financial system vulnerabilities. Journal of International Money and Finance 39: 153-185. https://doi.org/ 10.1016/j.jimonfin.2013.06.023.

24. Crowe, C., G. Dell'Ariccia, D. Igan, and P. Rabanal. 2013. How to deal with real estate booms: Lessons from country experiences. Journal of Financial Stability 9(3): 300-319. https://doi.org/10. 1016/j.jfs.2013.05.003.

25. De Jonghe, O., H. Dewachter, and S. Ongena. 2020. Bank capital (requirements) and credit supply: Evidence from pillar 2 decisions. Journal of Corporate Finance. https://doi.org/10.1016/j. jcorpfin.2019.101518.

26. Deutsche Bundesbank. 2018. The importance of bank profitability and bank capital for monetary policy Deutsche Bundesbank Monthly Report, January. https://www.bundesbank.de/resource/ blob/667588/bf422c75deafad8185444765bf3f722e/mL/2018-01importance-of-bank-data.pdf.

27. Dumičic, M. 2018. Effectiveness of macroprudential policies in Central and Eastern European countries Public Sector. Economics 42(1): 1-19. https://doi.org/10.3326/pse.42.1.1.

28. European Banking Authority. 2015. Report-2015 EU-wide transparency exercise. https://www.eba.europa.eu/sites/default/docum ents/files/documents/10180/1280458/106bdfd6-8c0f-4251-ba577cd0d97d8174/2015\%20EU-wide\%20Transparency\%20Exe rcise\%20Report\%20FINAL.pdf.

29. Fendoğlu, S. 2017. Credit cycles and capital flows: Effectiveness of the macroprudential policy framework in emerging market economies. Journal of Banking \& Finance 79: 110-128. https:// doi.org/10.1016/j.jbankfin.2017.03.008.

30. Fonseca, A.R., F. González, and Pereira da Silva, L. 2010. Cyclical effects of bank capital buffers with imperfect credit markets: International evidence Banco Central do Brasil Working Paper No. 216. https://econpapers.repec.org/RePEc:bcb:wpaper:216.

31. Galati, G., and R. Moessner. 2018. What do we know about the effects of macroprudential policy? Economica 85(340): 735-770. https://doi.org/10.1111/ecca.12229.

32. Gambacorta, L., and H.S. Shin. 2018. Why bank capital matters for monetary policy. Journal of Financial Intermediation 35(B): 17-29. https://doi.org/10.1016/j.jfi.2016.09.005.

33. Geršl, A., and M. Jašová. 2014. Measures to tame credit growth: Are they effective? Economc Systems 38(1): 7-25. https://doi.org/ 10.1016/j.ecosys.2013.10.001.

34. Hancock, D., and J.A. Wilcox. 1993. Has there been a "capital crunch" in banking? The effects on bank lending of real estate market conditions and bank capital shortfalls. Journal of Housing Economics 3(1): 31-50. https://doi.org/10.1006/jhec.1993.1003.

35. Heid, F., D. Porath, and S. Stolz. 2003. Does capital regulation matter for bank behaviour? Evidence for German Savings Banks (Mimeo). https://doi.org/10.2139/ssrn.493723.

36. Hodrick, R.J., and E.C. Prescott. 1997. Postwar U.S. business cycles: An empirical investigation. Journal of Money, Credit and Banking 29(1): 1-16.

37. Imbierowicz, B., A. Löffler, and U. Vogel. 2021. The transmission of bank capital requirements and monetary policy to bank lending in Germany . Review of International Economics 29(1): 144-164. https://doi.org/10.1111/roie.12500.

38. Jiménez, G., S. Ongena, J.-L. Peydró, and J. Saurina. 2017. Macroprudential policy, countercyclical bank capital buffers, and 
credit supply: Evidence from the Spanish dynamic provisioning experiments. Journal of Political Economy 125(6): 2126-2177. https://doi.org/10.1086/694289.

39. Kapuściński, M. 2017. The role of bank balance sheets in monetary policy transmission: Evidence from Poland. Eastern European Economics 55(1): 50-69. https://doi.org/10.1080/00128775. 2016.1255559.

40. Kuttner, K.N., and I. Shim. 2016. Can non-interest rate policies stabilize housing markets? Evidence from a panel of 57 economies. Journal of Financial Stability 26: 31-44. https://doi.org/10. 1016/j.jfs.2016.07.014.

41. Laeven, L., and F. Valencia. 2013. Systemic banking crises database. IMF Economic Review 61(2): 225-270. https://doi.org/10. 1057/imfer.2013.12.

42. Labra, R., and C. Torrescillas. 2018. Estimating dynamic panel data. A practical approach to perform long panels. Revista Colombiana de Estadística 41(1): 31-52. https://doi.org/10.15446/rce. v41n1.61885.

43. Lee, J.K. 2013. The operation of macroprudential policy measures: The case of Korea in the 2000s BOK Working Paper No. 2013-1. https://doi.org/10.2139/ssrn.2552975.

44. Lee, M., R.C. Asuncion, and J. Kim. 2016. Effectiveness of macroprudential policies in developing Asia: An empirical analysis. Emerging Markets Finance and Trade 52(4): 923-937. https:// doi.org/10.1080/1540496X.2015.1103137.

45. Lim, C., F. Columba, Costa, A., Kongsamut, P., Otani, A., Saiyid, M., Wezel, T., and Wu, X. 2011. Macroprudential Policy: What Instruments and how to use them? Lessons From Country Experiences IMF Working Paper No. WP/11/238, https://doi.org/10. 5089/9781463922603.001.

46. Meuleman, E., and Vennet R. Vander. 2020. Macroprudential policy and bank systemic risk. Journal of Financial Stability. https:// doi.org/10.1016/j.jfs.2020.100724.

47. Ostry, J.D., A.R. Ghosh, M. Chamon, and M.S. Qureshi. 2012. Tools for managing financial-stability risks from capital inflows. Journal of International Economics 88(2): 407-421. https://doi. org/10.1016/j.jinteco.2012.02.002.

48. Poghosyan, T. 2020. How effective is macroprudential policy? Evidence from lending restriction measures in EU countries. Journal of Housing Economics. https://doi.org/10.1016/j.jhe.2020. 101694.
49. Richter, B., M. Schularick, and I. Shim. 2019. The costs of macroprudential policy. Journal of International Economics 118: 263 282. https://doi.org/10.1016/j.jinteco.2018.11.011.

50. Roodman, D. 2009. A note on the theme of too many instruments. Oxford Bulletin of Economics and Statistics 71(1): 135-158. https://doi.org/10.1111/j.1468-0084.2008.00542.x.

51. Schularick, M., and A.M. Taylor. 2012. Credit booms gone bust: Monetary policy, leverage cycles and financial crises, 1870-2008. The American Economic Review 102(2): 1029-1061.

52. Tillmann, P. 2015. Estimating the effects of macroprudential policy shocks: A Qual VAR approach. Economics Letters 135: 1-4. https://doi.org/10.1016/j.econlet.2015.07.021.

53. Tovar, C.E., M. Garcia-Escribano, and Vera Martin. M. 2012. Credit growth and the effectiveness of reserve requirements and other macroprudential instruments in Latin America IMF Working Paper No. WP/12/142. https://doi.org/10.5089/9781475503999. 001.

54. Vandenbussche, J., U. Vogel, and E. Detragiache. 2015. Macroprudential policies and housing prices: A New database and empirical evidence for Central, Eastern, and Southeastern Europe. Journal of Money, Credit and Banking 47(1): 343-377. https://doi.org/10. 1111/jmcb.12206.

55. Zhang, Y., and T. Tressel. 2017. Effectiveness and channels of macroprudential policies: Lessons from the Euro area. Journal of Financial Regulation and Compliance 25(3): 271-306. https:// doi.org/10.1108/JFRC-10-2016-0094i7.

56. Zhang, L., and E. Zoli. 2016. Leaning against the wind: Macroprudential policy. Asia Journal of Asian Economics 42: 33-52. https://doi.org/10.1016/j.asieco.2015.11.001.

Publisher's Note Springer Nature remains neutral with regard to jurisdictional claims in published maps and institutional affiliations.

Marcin Czaplicki is an Assistant Professor at the Warsaw School of Economics and Expert in Economic Research Department at PKO Bank Polski. He is a CFA Charterholder. His research interests are: macroprudential policy, monetary policy and bank lending activity. 